\title{
The Problems in Current Higher Education
}

\author{
Nguyen Thi Kim Hoa
}

\begin{abstract}
Education at any time and in any clime or country always plays a vital role in shaping the destiny of the people. Education has always been a core value in society and the overriding concern for most country is invest much time, money in education. A good education not just for the rich and powerful, it should be for all, regardless of their wealth, their religion or their cultural background. Good education must provide opportunities for the poor, for the disabled person, for those who less intelligent, even for the people have difficulty on the psychologically.

The purpose of this paper is to make us understand our problem in current higher education and finally in an ongoing effort to develop the necessary policy response to address these problems.
\end{abstract}

Keywords - core value, good education, current higher education

\section{INTRODUCTION}

Ladies and gentlemen, thank you so much for coming here today. I am a foreign student, I come from Viet Nam. Now, I'm studying at Allahabad University in India. People remember my country only as war - worn, but they do not see Viet Nam is known as an emerging economy country. Today, Dubai is the fastest growing economy in the world and in Dubai any kids brought up in an ideal classless society may not feel the difference created by birth or conditions, but what about the poor countries? so the purpose of my presentation is: The problems in current higher education.

Firstly, I will talk about the problem of current higher education in detail. Next, I will look at the figures are reported by the studies in various publications, and finally allow me to pose a very much related question for our discussion what do you go to conference for? I hope we will have found the best solutions to problems our in current higher education.

\section{II.THE PROBLEMS IN CURRENT HIGHER EDUCATION NEED TO BE ADDRESSED}

As we know, the historical development of human civilization has changed from Stone Age to the peak of scientific civilization today, and we witnessed the most events in the history of science, on 10 May 2016 NASA announced that: "1,284 new exoplanets have been discovered by the Kepler space telescope" .

Thus no coincidence that the significant inventions in science and in any field are come out in zones where education

Author Nguyen Thi Kim Hoa, Research Scholar,Department of Philosophy University of Allahabad, Allahabad, 211002

\footnotetext{
${ }^{1}$ Source from an article in the www.mirror.co.uk by Jeff Parsons. For further details see Jeff Parsons, 2016. "NASA's Kepler space announcement RECAP: Planet-hunting satellite to reveal new alien world", the pages of the www.mirror.co.uk website, 10 May 2016.
}

development and in order to shaping the 21st Century based on these studies scientists have suggested that education must be the highest importance for every community of developing countries. In the context of globalization present, the leaders of the world often talk about the concept of freedom, fairness in the world is becoming "flat" or globally interconnected thereby allowing so easy for people all over the world access to modern education as with other field.

Meanwhile, human being is optimistic and believes that globalization has made all countries equality of opportunity in the flat world there is boundary. But, from the harsh realities of society has shown that in developed countries have better education programs than that of other developing countries or poor and under - developed countries, why these giant disparities, even within the world is flat?. All of these countries has long recognized the significance of education and value of education in the development their countries.

In fact modern and developed countries pay huge attention to education, which means their teachers do big help nation building, due to if we want our country flourish in the present economic climate we must invest in the education. There is no progress of science without education, hence future challenges for our education or the issues and problems in secular education will therefore as much to brilliance as to entrance.

In the context of globalization education is the extreme important issue, but current education system is based on an outmoded process and ideas deeply rooted in the traditional way of thinking or ancient age. Modern age is era knowledge alongside with offers opportunities for under developed countries, concurrent it creates many difficulties and new challenge for the education system. That is why the issue of education has origin great controversy from the past until now.

The continued advance of civilization are so beneficial for humans, but besides we have also had to face many problems in the educational field. The issues and problems in secular education these contain a large educational systems, organizations, doctrines belong to religious or non religious, according to many critics point out that one of the issues we are facing such as:

1. Problem of the objectives of education

2. Problem of primary and compulsory education

3. Problem of secondary education and higher education

4. Problem of technical education

5. Problem of special education

6. Problem of teachers and student unrest

7. Problem of finance

8. Problem of moral and spiritual values

9. Problem of inequality 


\section{Problem of educational structure etc... ${ }^{2}$}

All of the issues in series above concerning about human development, embraces individual development just like social and national development. However, to implementation objectives we must force more on training man, a rounded view of life, those were the individual full of meaning - a collection of the entire spiritually, physically, ethically, knowledge, personality. But it's easy to see which setting your objectives in the education has not met its goals. Today, the numerous issues that are afflicting education obviously globalization isn't the only origin of problem of the objectives of education, the main problem lies in the irrational training system, many issues of education such as universalize education and improve education quality still remains unsolved. Although the objective of education is the find and the individual development through suitable training to innate potential each individual.

As mentioned above in many problem such as primary and compulsory education, secondary education and higher education, finance, inequality etc...is very serious this is a true analysis for millions children in the world are now still excluded from right to secular education, although in any country and society always declared that everyone has the right to education. ${ }^{3}$ As analyzed above, finance was factors that obstruct women, children in gaining access to education in under developed countries such as Africa, sub-Saharan Africa, Southeast Asia, Middle Asia, where the problems of extreme poverty have a substantial influence on admission rates and pass in primary education for this areas, furthermore the problems of unemployment interferes with school work, unemployment problem not only is a big deal lead to untaught but also is the main cause of child labour, because have to do laborious works to earn a few money for which they paid the food and cover other expenses so they don't have time come to school, they could not afford to buy a bicycle, let alone complete secondary education and higher education, especially children living in conflict areas.

According to numerous studies by $\mathrm{FAO}^{4}$ have shown that:

- "No country has ever achieved rapid and continuous economic growth without at least a $40 \%$ literacy rate.

- Worldwide, 124 million children and adolescents are not in school - and the number is rising.

- Of these 1 in 11 (59 million) are primary school aged (611), and 30 million are in sub-Saharan Africa.

- Girls are the first to be excluded: 16.7 million girls in subSaharan African are not in school, and over half of them will not get a single year of education." $"$... etc

\footnotetext{
2 In fact, have numerous issues about secular education we need to discussion, the problem of secular education above-mentioned have been excellent studies and was the result of surveying from many researchers and scientists worldwide, these are research perceptive analysis in the current education system. These issues was discussed by many scholar research, on this, see P. Annie Amala, P. Anupama, D. Bhaskara Rao Eds., History of Education, Published by Discovery Publishing House, Delhi, 2004, pp. 1-10.

${ }^{3}$ For further detail see Damien V. Keown, Charles S. Prebish, Wayne R. Husted Eds., Buddhism and Human Rights, Published by Curzon Press, Great Britain, 1998, p.15.

${ }^{4}$ FAO is the abbreviation for Food and Agriculture Organization of the United Nations. For the source material on this and other related can be found at: http://www.fao.org/.
}

The research was done by leaders profoundly involved with education in the past years point out that in the Middle East and North Africa there are "Eighty million young people are now formally registered as unemployed" and the numbers of hasn't stopped here:

"There will still be 50 million children out of school in 2050, and 50 years from now education for all will still be a distant dream. Contrary to accepted wisdom, the world is not on a smooth, irreversible upward path to universal education, and, for millions, equality of opportunity will remain a hollow promise, its absence a growing source of unrest." 6

Thus the problem of primary and compulsory education is considered as the most crucial part of rights to education, we're impracticable about the problem of secondary education and higher education in the secular education, compulsory education and secondary education is one of the major responsibility of the national for the solidity of democracy, it made right to education a basic fundamental right. Now we will be analyze and solve problem of technical education and problem of special education.

Well, as we know nowadays we live in a digital age, there's no denying the benefits of the Internet in daily life. Just a click of the mouse, the whole world has appeared in our eyes, the popularity of technology today made to close gaps in regions. However, the growing gap between the illiterate and whose who receive equality education and that's why problem of inequality have arisen.

As we known, the Industrial Revolution in the middle of 19th century was a momentous turning - point of human's history, that is the restructuring from the agricultural economy to an industrial economy and nowadays is the knowledge economy, and specific characteristics of knowledge economy was built by the education and training in technology. The present day thanks to the great progress of science people's cultural, economic and spiritual life has better, however the development of education, training, and healthcare only for developed countries.

Let India be an example for the growth of the software industry in the world. A fact cannot be deny, India has become the world's most genius providers with many preeminent leaders such as Jawaharlal Nehru, Mahatma Gandhi, the profound philosophers, the radical thinkers especially in the economic India is the home of outstanding CEO like Satya Nadella - CEO of Microsoft Corporation, Indra Nooyi - CEO of PepsiCo, Sundar Pichai - CEO of Google, Ajaypal Singh Banga - CEO of MasterCard etc... But in fact, there are many harsh problems unresolved, a study was published the front page of The Hindu newspaper point out that: "Over

\footnotetext{
${ }^{5}$ See "Education is the single best investment in prosperous, healthy and equitable societies." 16 May 2016 20: 33:39GMT. For the source material on this and other related can be found at: http://www.canadianfeedthechildren.ca/what/education.

${ }^{6}$ For the source material on this and other related can be found at: http://www.nationmultimedia.com/opinion/Education-can-replace-loss-ofhope-in-poorest-coun-30192240.html. See also Gordon Brown. (2012) "Education can replace loss of hop in poorest countries", October 13, 2012 12:00 am. Gordon Brown, the former prime minister of Great Britain, is the United Nations special envoy for global education.
} 
$45 \%$ children found to have stunted growth, $43 \%$ acutely malnourished". 7

For India, as a result in 2014 based on an analysis by UNESO showed that: "...a total of 17.8 million children between the ages 5 to 13 were out of school in India" 8 . Thus we can see very obviously that India was the nation success in the software industry - rank first now in the world, but we failed in the problem of primary and compulsory education, and unsolved problem of primary and compulsory education, secondary education may closed future of million children.

\section{HOW TO FIND A GOOD RESOLUTION FOR THESE PROBLEMS?}

Based on a sober analysis of what issues developing we can conclude here that no access to education because the cause poor, also means cannot maintain the special right in the problems of higher education, special education, technical education, language.

Therefore, wasn't that hard to find out numerous problems existing, such as the economic, finance, inequality in society and sex discrimination, etc... and a big problem in secular education that the gap between rich and poor, and gaps in literacy and enrolment rates still remains in the less developed countries. As the gap between developed countries and underdeveloped countries increases, is necessarily synonymous with poverty, illiteracy, backwardness, inequality, therefore have access to quality education remains a challenge for many children and the poorest members of society, in underdeveloped countries. The disadvantages of underdeveloped countries lead to condition children very hard to adopt modern education. In other words, a serious inequality be present in accessing higher education, technical education opportunities.

Thank you all for listening; it was a pleasure being here today.

\section{REFERENCE}

[1] Jeff Parsons, 2016. "NASA's Kepler space announcement RECAP: Planet-hunting satellite to reveal new alien world", http://www.mirror.co.uk/science/nasas-kepler-space-announcementrecap-7938930, 10 May 2016.

[2] P. Annie Amala, P. Anupama, D. Bhaskara Rao Eds., History of Education, Published by Discovery Publishing House, Delhi, 2004, pp. $1-10$.

[3] Damien V. Keown, Charles S. Prebish, Wayne R. Husted Eds., Buddhism and Human Rights, Published by Curzon Press, Great Britain, 1998, p.15.

[4] http://www.fao.org/.

[5] "Education is the single best investment in prosperous, healthy and equitable societies." 16 May 2016 20: 33:39GMT. For the source material on this and other related can be found at: http://www.canadianfeedthechildren.ca/what/education.

[6] Gordon Brown. (2012) "Education can replace loss of hop in poorest countries", October 13, $2012 \quad 12: 00 \quad$ am. http://educationenvoy.org/petition.

[7] Bindu Shajan Perappadan, 2015 "Half of Delhi slum kids underweight: CRY", The Hindu, Wednesday, November 4, p.1.

${ }^{7}$ For further detail see Bindu Shajan Perappadan, 2015 "Half of Delhi slum kids underweight: CRY”, The Hindu, Wednesday, November 4, p.1.

${ }^{8}$ For the source material on this and other related can be found at: http://www.oxfamindia.org/education/Still-too-many-children-out-of-school. For further detail see India's missing millions of out of school children: A case of reality not living up to estimation?, Nov 2, 2015.
[8] http://www.oxfamindia.org/education/Still-too-many-children-out-ofschool. India's missing millions of out of school children: A case of reality not living up to estimation?, Nov 2, 2015. 